\title{
Morphological Identification of Babylonia spirata (Linnaeus, 1758) from Tuticorin Coast, Gulf of Mannar
}

\author{
G Chella Durai* \\ Research Department of Zoology, VOC College, India \\ *Corresponding author: G Chella Durai, PG \& Research Department of Zoology, VOC College, Tuticorin, Tamil Nadu, India
}

Submission: July 12, 2018; Published: 㪙 August 03, 2018

\begin{abstract}
Marine gastropods are generally having a tremendous impact on Indian tradition and economy and are popular among the common man as ornaments and currency. The present study deals with morphological analysis of B. spirata from Tuticorin coast, Gulf of Mannar. Morphologically, this species was analysed with reference to shell, mantle, operculum, head tentacle, foot and visceral complex.
\end{abstract}

Keywords: Morphological analysis; Babylonia spirata; Tuticorin coast; Gulf of Mannar

\section{Introduction}

The taxonomy is an integral part of any biological study. Scientific studies involving a taxon must have an accurate identification of that taxon. In the past, morphology alone sometimes fails as an effective identifier of species [1]. In the cases of morphologically similar species, or where the specimens are derived from larval or juvenile life stages, the usefulness of traditional methods of comparative morphology could be limited [2]. Furthermore, traditional taxonomy is heavily dependent on specialists whose knowledge is usually lost when they retire, thus there is a need for a novel scheme that would preserve taxonomic information and knowledge and make these more accessible [3].

The order Neogastropoda is one of the mostabundantand diverse groups of marine gastropods, around more than 5200 species [4]. The number of families recognized within Neogastropoda varies to a great extent from 15 to 34 [5]. It is generally accepted that evolution of the order, as well as that of other gastropod species was determined mainly by the changes in the anatomy of the digestive system, while the similarity of shells is often the result of convergence [6]. Much attention has been paid to the anatomy of the digestive system and current phylogenetic analyses of the higher classification of Neogastropoda have been based mainly on anatomical characters of the digestive system especially on the foregut [7-9]. Similarly, discrimination of the families within the Neogastropoda has traditionally been based on radular and other foregut characters. The stomach of Neogastropoda remains a poorly studied structure. Only very few publications dedicated entirely to stomach morphology and its comparative analysis. For gastropod tissues, however there is only very few information available on the morphological status. Therefore, in this study the morphological status of B. spirata was carried out.

\section{Materials and Methods}

\section{Sample of Babylonia spirata (Linnaeus, 1758)}

Live animals of $B$. spirata were collected from Therespuram coast, Tuticorin, Tamil Nadu, India $\left(80^{\circ} 48^{\prime} \mathrm{N} ; 7^{\circ} 94^{\prime} \mathrm{E}\right)$. Immediately after the collection, samples were stored in the ice box and brought to the laboratory. Then, the species were identified based on their morphological characters.

\section{Morphological examination of Babylonia spirata}

Morphological characteristics of the shell and internal tissue were also examined.

Results

\section{Morphological description of the Babylonia spirata}

The whelks were categorized under the order of Neogastropoda and family Buccinidae. They are mostly carnivorous and scavengers. In India B. spirata were observed to be landed, mostly in the bottom trawls and rarely in crab net.

Habitat: It thrives well on muddy bottom of marine environment. Whereas salinity below 19ppt was observed to be lethal. The Babylonia species mostly preferred in coarse sand.

Food: It is a carnivore and readily accepts calm meat as food.

Copyright $\odot$ All rights are reserved by G Chella Durai. 
Growth: The laboratory studies indicated that the settlement after a day old juvenile have attained are average shell length $1.58 \mathrm{~mm}$, average total weight $0.009 \mathrm{~g}$ attain of an average shell length of about $34.3 \mathrm{~mm}$ and the total weight of $9.137 \mathrm{~g}$.

Head: The body is externally divided into three regions viz, head, foot and visceral mass. The head was observed to be bilaterally symmetrical with a pair of black coloured eyes at the base of the lateral side. The colour of the head is brown with blackish pigmentation.

Tentacles: Two pairs of contractile cephalic tentacles are present on either side of the snout which measure about $3 \mathrm{~mm}$ and $5 \mathrm{~mm}$ in length. It depends upon the size of the animal.

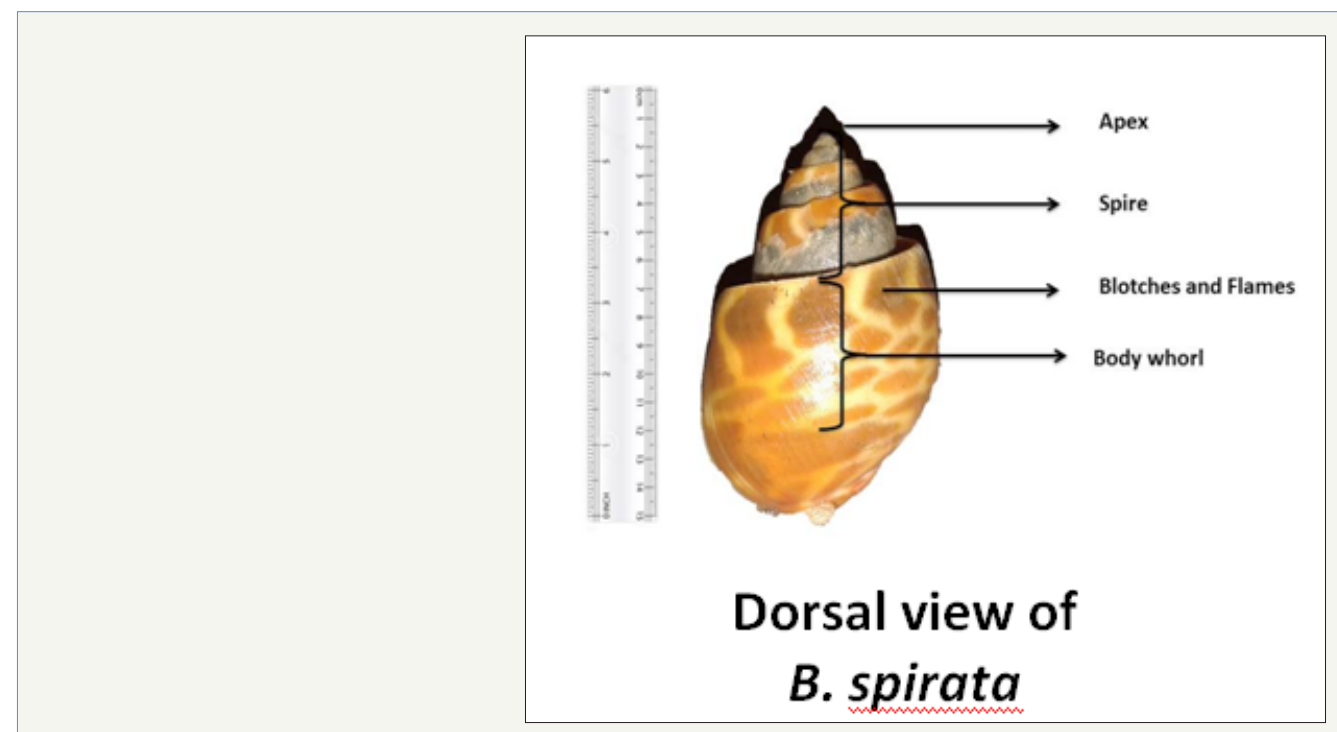

Figure 1: Dorsal view of Babylonia spirata.

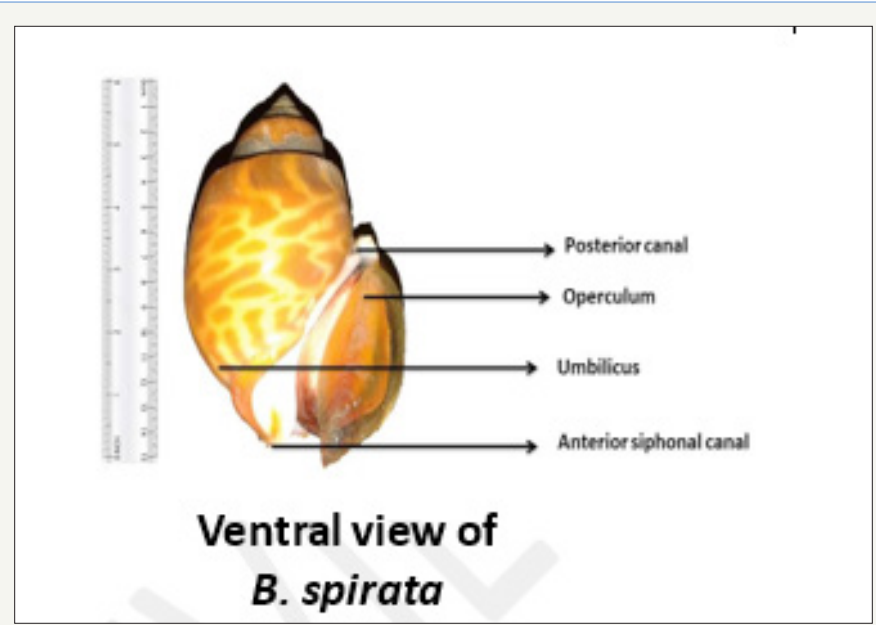

Figure 2: Ventral view of Babylonia spirata.

Shell: The shell of B. spirata was observed to be thick, void with a horny surface. The shell shows a characteristic colour pattern and consisted of regular spiral rows of round bright brownish patches on a white background. The apex of the shell the oldest part and showed a reverse coiling. The umbilicus was found to be either closed or open. It has a smooth surface. Its apex (spire) was observed to be well elevated with conical shape and the in flatted whorls are inflated. The whorls are six or seven in number and lie very close to each other (Figure $1 \& 2$ ).

Foot: The foot is a muscular organ with a broad ventral creeping sole occurring on the ventral side of the head. It has reddish brown pigmentation and is capable of expansion and concentration. The animal having the shell length of about $60 \mathrm{~mm}$ possessed of about $32 \mathrm{~mm}$. Whereas it measures about $50-70 \mathrm{~mm}$ in length and 40 $50 \mathrm{~mm}$ in width during contraction (Figure 3).

Mantle: The mantle encircles the neck region of the animal like a collar. It was observed to be broad dorsally and its width narrows down rapidly towards the posterior region, where it forms a slight ridge-like structure. Posteriorly, it possesses a continuous wall continuous with the visceral mass. Whereas, anteriorly the dorsal side of the mantle is drawn out into a siphon, which extends thorough the siphoned canal exteriorly. Its edge involves in the secretion of the shell and plays a major role in their glandular and sensory activities (Figure 3). 


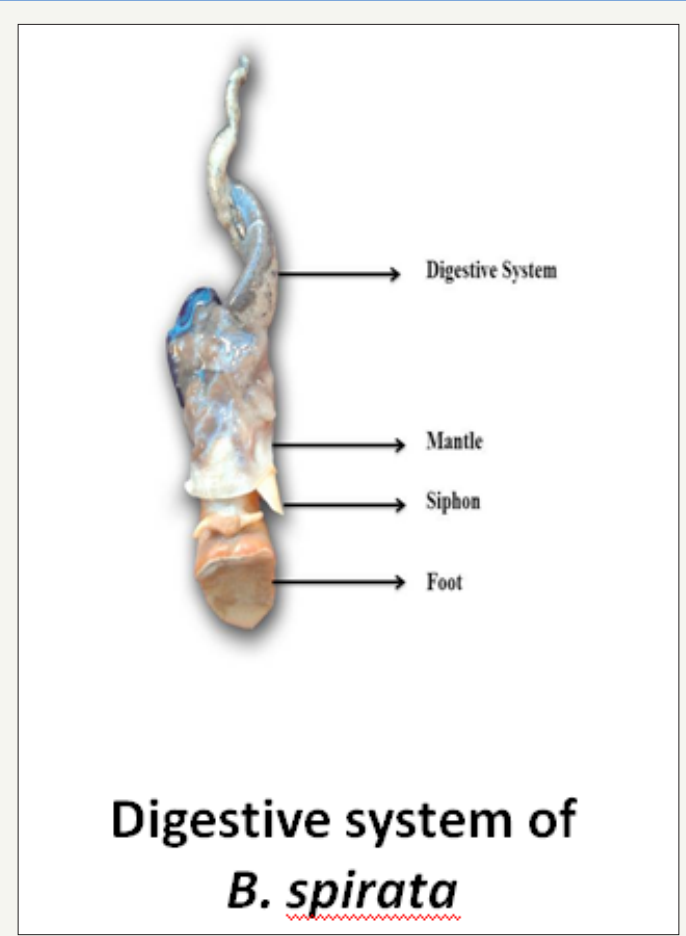

Figure 3: Digestive system of $B$. spirata.

Operculum: The operculum was found to be at the poster dorsal region of the foot. It is oval in shape horny and chitinous in nature with a terminal nucleus. The concentric rings called lines of growth surround the nucleus. The operculum has 8 to $10 \mathrm{~mm}$ concentric bands. The numbers of bands are lesser and appear to be a transparent in the immature forms. The adult B. spirata operculum has a maximum length and width ranged from $32 \mathrm{~mm}$ and $18 \mathrm{~mm}$ with clean line growth (Figure 4).
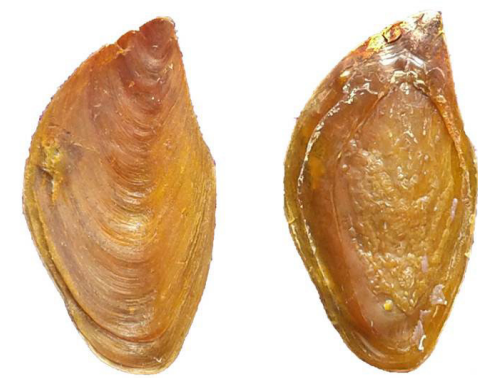

Anterior

\section{Posterior}

Figure 4: Anterior and Posterior view of operculum of B. spirata.

Visceral complex: The distal end of the hind region of the body is occupied by the visceral mass; which contains the stomach, the digestive diverticula and gonads. The stomach is irregular in shape, elongated in anterior-posterior direction, embedded in the anterior region of the midget gland. The midget gland occupies the major part of the visceral mass. The gonad covers the stomach on the dorsal side and it exhibits different colours in accordance with the reproductive phase of the animal.

\section{Reproduction}

Sexes are separate. Snails of about $20 \mathrm{~mm}$ shell length are considered as of matured adults. The sex ratio between males and females is 1:1 Sexes cannot be distinguished from size and shell colour. The testis is yellow or orange and the ovary is dark brown in colour. Fertilization is internal.

\section{Systematic position}

Based on the morphological observation the test gastropod was placed under the following systemic position
A. Phylum: Mollusca
B. Class: Gastropoda
C. Order: Neogastropoda
D. Family: Buccinidae 


\section{E. Genus: Babylonia}

F. Species: spirata

\section{Discussion}

In the classical taxonomy a family is more precise than orders but less precise the genera. Organisms belonging to the same family would have evolved from the same ancestors and share relatively common characters. The family Buccinidae belongs to the subclass ortho gastropods which has a characteristic outer dextral shell with eight whorls. Due to this noticeable characteristic feature the test gastropod, is placed under to the family Buccinidae [10]. The Neogastropoda have adapted well to almost every marine environment commencing with an explosive radiation during the cretaceous period [11]. The monopoly of the group based on their notable several synapomorphies, which mostly related with the anatomy of their digestive system $[12,13]$. The phylogenetic relationships of Neogastropoda were based on their morphological characters remains to be unclear, still toady [14]. Whereas, genus Babylonia sp under the family Buccinidae of Buccinidae (super family) [15]. The use of morphological techniques seems to have a profound impact on systematic zoology and phylogentic research. Many studies have depicted that the molecular phylogenetic analysis is a powerful tool for elucidating the evolution of the molluscs' fauna [16].

Similarly, reported that the phylogenetic relationships were made on the basis of the morphological features remains uninvestigated till today [17]. Therefore, these morphological analyses were carried out on the base of operculum and shell seems to be a valuable tool for this investigation regarding the evolutionary relationships among the gastropod families. Today, additional genetic information and increased sampling seems to be trust worthy and provides a new insight into this study of phylogenetic relationship between all Indian species of Neogastropoda.

Nowadays the aquacultures of this species were observed to be gradually developing. But, it surely requires more molecular markers for genetic resource management and for conducting breeding programmes, interestingly, the above mentioned could be made possible by the usage of micro satellite markers. It might hope fully leads to produce a good quality product, which could be easily marketed in the future. Moreover, from the morphological observations; the test gastropods occupy the family Buccinidae (Morphological description of (B. spirata). Moreover, seems to the morphological relationship studies provides a better resolution of linearity among the gastropods when compared with the classification based on morphology and other traits.

\section{Acknowledgement}

I wish to thank the authorities of Kamaraj College for providing the necessary facilities, and the Centre for Marine Living Resources and Ecology (CMLRE), Project (Grant No. MoES/10-MLR/01/12), Government of India for their financial support.

\section{References}

1. Packer L, Gibbs J, Sheffield C, Hanner R (2009) DNA barcoding and the mediocrity of morphology. Mol Ecol Resour 9(Suppl 1): S42-S50.

2. Gossner M, Hausmann A (2009) DNA barcoding enables the identification of caterpillars feeding on native and alien oak (Lepidoptera: Geometridae). Mitt Münch Ent Ges 99: 135-140.

3. Tautz D, Arctander P, Minelli A, Thomas R, Vogler A (2003) A plea for DNA taxonomy. Trends in Ecology and Evolution 18(2): 70-74.

4. Taylor JD (1980) Diets and habitats of shallow water predator gastropods on the Esternatlantic shelf. Journal of Biogeogr 4: 7-81.

5. Golikov A, Starobogatov YI (1988) Problems of phylogeny and system of the prosobranchiate gastropods. Proceedings of the Zoological Institute 187: 4-77.

6. Kohn (1983) Feeding biology of gastropods. In: Saleuddin ASM, Wilbur KM (Eds.), The Mollusca Academic press, New York, USA, pp. 1-63.

7. Ponder W (1974) The origin and evolution of the Neogastropoda. Malacologia 12: 295-338.

8. Kantor YI (1966) Phylogeny and relationships of Neogastropoda. In: Taylor JD (Ed.), Origin and evolutionary radiation of the Mollusca, pp. 221-230.

9. Kantor YI, Taylor JD (2002) Foregut anatomy and relationships of raphitomine gastropods (Gastropoda: Conoidea: Raphitominae). In: Oliverio M, Chemello R (Eds.), Systematics, phylogeny and biology of Neogastropoda. Bolletino Malacologico, 5: 83-110.

10. Ponder WF, Lindberg DL (1994) Towards a phylogeny of gastropod molluscs: An analysis using morphological characters. Zoological Journal of the Linnean Societ 119(2): 83-265.

11. Bouchet P, Rocroi JP (2005) Classification and nomenclature of gastropod families. Malacologia 47(1-2): 1-397.

12. Ponder WF, Colgan DJ, Healy JM, Nutzel A, Simone LRL, et al. (2008) Caenogastropoda. In: Ponder WF, (Ed.), Phylogeny and Evolution of the Mollusca. University of California Press, Berkeley, USA, pp. 331-383.

13. Ramasamy H, Chellam B, Moon SH (2011) Diet enriched with mushroom Phellinuslinteus extract enhances the growth, innate immune response, and disease resistance of kelp grouper, Epinephelusbruneus against vibriosis. Fish Shellfish Immunol 30(1): 128-134.

14. Cunha RL, Grande C, Zardoya R (2009) Neogastropod phylogenetic relationships based on entire mitochondrial genomes. BMC Evol Biol 9: 210.

15. Heulsken T (2008) Phylogenetic relationship and species identification within the Naticidae Guilding, 1834 (Gastropoda: Caenogastropoda). Doctroal Thesis, Ruhr University, Germany, pp. 444.

16. Colgan DJ, Ponder WF, Eggler PE (2000) Gastropod evolutionary rates and phylogenetic relationships assessed using partial 28S rDNA and histone $\mathrm{H}_{3}$ sequences. Zool Scripta 29(1): 29-63.

17. Park JK, Foighil D (2000) Sphaeriid and corbiculid clams represent separate heterodont bivalve radiations into freshwater environments. Mol Phylogenet Evo 14(1): 75-88. 
(c) Creative Commons Attribution 4.0 International License

For possible submissions Click Here
SBB

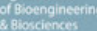
ofos:

\section{Significances of Bioengineering \& Biosciences}

\section{Benefits of Publishing with us}

- High-level peer review and editorial services

- Freely accessible online immediately upon publication

- Authors retain the copyright to their work

- Licensing it under a Creative Commons license

- Visibility through different online platforms 